\title{
Physico-Chemical and Cooking Properties of Some Rice Varieties to Produce Salty and Sweet Puffed Rice
}

\author{
Wafaa K. Galal, Gomaa R. A. \& Maha, M. Tawfik \\ Crops Technology Department, Food Technology Research Institute, Agricultural Research Center, \\ Al-Giza, Egypt
}

Received: 18 May, 2019

Revised: 16 June, 2019

Accepted: 30 June, 2019

\begin{abstract}
To determine the possibility of producing puffed snacks from rice grains, physical, chemical, cooking and puffing properties of three rice varieties, namely Sakha 101, Giza 178 and Egyptian Jasmine beside one Basmati type were investigated. Results showed that Sakha 101 has the highest percentage of brown, milled and head rice and the lowest hulls and broken rice percentage followed by Giza 178. While for broken rice character, Egyptian Jasmine showed the highest percentage of broken rice followed by Sakha 101 and Giza 178. Moreover, the results reported that there were significant differences in the protein contents between Sakha $101(8.23 \%)$ and the other studied varieties being 7.1, 7.35 and $6.72 \%$ for Giza 178, Egyptian Jasmine and Basmati grain rice, respectively. As for puffed yield character, Basmati grain showed the highest yield 96.72 followed by Egyptian Jasmine rice (96.1\%), then Giza 178 tailed behind (93.56\%). Sakha 101 had the highest expansion volume, whereas, Egyptian Jasmine had the lowest expansion volume. No significant differences in expansion ratio character in Sakha 101, Giza 178 and Basmati grains. Egyptian Jasmine had the lowest expansion ratio. The results of organoleptic evaluation for the prepared salty puffed rice indicated that, the samples of salty puffed rice from Sakha 101 recorded better scores for crispness and taste characters compared with other salty puffed rice samples. Moreover, no significant differences were found in flavour and overall acceptability for all salty puffed rice samples. On the other hand, all sweaty puffed rice samples belonging to different varieties showed a good overall acceptability. It can be recommended that, salty and sweet puffed rice could be prepared from different varieties of rice..
\end{abstract}

Keywords: Rice varieties - Chemical composition-cooking properties- physical characteristics-puffed rice.

\section{INTRODUCTION}

More than $65 \%$ of the world's population consumes rice as a main food. According to the Department of Agriculture, Cooperation \& Farmers Welfare, in 2017, the production of rice reached about 473 million tons in 2015-2016 next to maize and wheat grains. Rice provides about $60-70 \%$ of the total energy, third of daily protein requirement. (Maisont and Narkrugsa, 2009; Joshi et al., 2014).

Basmati rice is an extra-long grain of rice variety grown in some parts of the world like India and Pakistan. The grain is well known for its slight nutty flavour, softness, smooth texture, palatable taste and delightful scent after cooking, the grain remains non-sticky, with excellent aroma, sweet taste and post cooking elongation of more than twice its original length.

Nowadays, health consciousness increase among the consumers due to the change in the lifestyle, where snack food became one of the most important products of the food industry. Developing snack foods today is considered as a very complex process to meet consumer's satisfaction and acceptability.

Puffed rice is a popular snack food in many countries. It is produced by parboiling the paddy rice followed by short time treatment in hot air or sand (Chinnaswamy \& Bhattacharya, 1983, Murugesan \& Bhattacharya, 1991).

Puffed rice processes healthy benefits due to its considerable amount of phytochemicals. (FDA, 2006, Seal et al., 2006). Puffed rice is characterized by crispness and lightness (Hoke et al., 2005).

Puffing of rice results in physical and conformational changes. Appropriate puffing technique and Puffing quality of rice energy based on input energy and salt concentration in the grain. An energy power of $29.21 \mathrm{~kJ}$ and salt level of $4.6 \%$ were found to be proper for puffing percentage and expansion rate of $98.26 \%$ and 5.826, respectively. (Shih, et al, 2007). 
The present study was conducted to investigate the possibility of using different rice varieties to produce salty and sweet puffed rice as a snack food.

\section{MATERIALS AND METHODS}

\section{Materials}

Three paddy rice varieties (Oryza sativa L.) namely, Sakha101, Giza 178 and Egyptian Jasmine, were obtained from Rice Research and Training Center (RRTC) at Sakha Research Station, Kafr El-Sheikh Governorate, Egypt. The three rice varieties were subjected to the recommended conditions for date of cultivation, fertilization, harvesting time and irrigation during the season of 2017. Milled Basmati grains rice were also employed in this study and obtained from local market, Al-Giza, Egypt. Frying oil, table salt, granulated sugar cane, glucose syrup, chili and cumin were purchased from, local market, Al-Giza, Egypt. All chemicals used were of analytical reagent grade.

\section{Methods}

\section{Milling and physical characteristics of dif-} ferent rice varieties

\section{Milling characteristics}

One hundred and fifty gram of cleaned rough rice varieties Sakha101, Giza 178 and Egyptian Jasmine were taken randomly. They were dehulled using Asatake Laboratory Dehuller. The total milled rice, brown rice, hulls, heads and broken percentages were calculated using the procedure of Khan \& Wikramanayake (1971). The milled rice kernels were kept at $-20{ }^{\circ} \mathrm{C}$ separately for further analysis.

\section{Physical characteristics}

The grain physical attributes namely, grain index, grain dimension (length and width) and grain shape (grain length to width ratio) were measured. The 100 grain from each variety of rice were counted randomly in triplicate, weighed separately and estimated as grain index $(\mathrm{g} \mid 100 \mathrm{~g})$. Grain length and width were measured using a micrometer with accuracy of $0.001 \mathrm{~mm}$ where 10 uniform rice grains were randomly selected and their length and width were measured in duplicate (Suwansri \& Meullenet, 2004). Grain shape was identified according to the classification reported by Kent \& Evers (1994) and Ahuja et al. (1995). Bulk density of rice was deter- mined according to the method of Myklestad et al. (1968).

\section{Cooking and eating quality}

\section{Alkali spreading value}

Alkali spreading value was determined using six kernels of different rice samples that were spaced in a Petri dish contained $10 \mathrm{ml}$ of potassium hydroxide solution (1.7). The dishes were covered and left at an incubator for $2-3 \mathrm{hr}$ at $255^{\circ} \pm \mathrm{C}$ according to the method described by Bhattacharya \& Sowbhagya (1980).

\section{Gel consistency $(\mathrm{mm})$}

Gel consistency was performed as described by Cagampang et al. (1973).

\section{Elongation percentage}

Kernel elongation of rice grain was measured using the method of Tomar (1985).

\section{Amylose content(\%)}

Amylose content of rice was determined according to Juliano et al. (1981)

\section{Minimum cooking time}

Rice samples $(2 \mathrm{~g})$ were taken in a test tube from each variety and cooked in $20 \mathrm{ml}$ distilled water in a boiling water bath $100+2^{\circ} \mathrm{C}$. The cooking time was determined by removing a few kernels at different time intervals during cooking and pressing between two glass plates until no white core was left.

\section{Water uptake ratio}

Two gram of samples rice samples were cooked in $20 \mathrm{ml}$ distilled water for a minimum cooking time in a boiling water bath $\left(100 \pm 2^{\circ} \mathrm{C}\right)$. The contents were drained and the superficial water on the cooked rice was sucked by pressing the cooked samples in filter paper sheets. The cooked samples were then weighed accurately and the water uptake ratio was calculated.

\section{Analytical methods}

\section{Chemical composition}

Chemical constituents (moisture, ash, crude protein, crude fiber, and fat content) of different rice samples (milled and puffed)were determined according to methods cited in the AOAC (2010). The nitrogen content was estimated by Kjeldahl method, and the nitrogen conversion factor of the crude protein calculation was 5.75. Nitrogen free 
extract was calculated by difference. The values obtained for protein, fat and carbohydrate were used to calculate the calorific content value of the samples as expressed AOAC (1995): calorific value $(\mathrm{kcal} / 100 \mathrm{~g})=\mathrm{P} \times 4.0+\mathrm{F} \times 9.0+\mathrm{C} \times 4.0$. Where, protein content $(\%)=\mathrm{P}$, fat content $(\%)=\mathrm{F}$, carbohydrate content $(\%)=\mathrm{C}$.

\section{Preparation of puffed rice}

Cooked milled rice grains were used to prepare puffed rice, then, the drained cooked rice was spread over a small wire-mesh trays, then dried at $40 \pm^{\circ} \mathrm{C}$ to $13-14 \%$ moisture content. The dried cooked milled rice was expanded in an iron pan containing frying oil $\left(180 \pm 20^{\circ} \mathrm{C}\right)$. Afterwards, the puffed rice was allowed to cool down at room temperature on a clean marble floor. The puffed samples were measured in a 100 and $500 \mathrm{ml}$ graduated cylinder. The puffed yield, expansion volume, expansion ratio and bulk density were calculated according to Simsrisakul(1991) using the following equations: -

$$
\begin{aligned}
& \text { Puffed yield }(\%)=\frac{\text { wt. of puffed rice }(\mathrm{g})}{\text { wt. of milled rice }(\mathrm{g})} \times 100 \\
& \text { Expansion volume }(\mathrm{ml} / \mathrm{g})=\frac{\text { vol. of puffed rice }(\mathrm{mL})}{\text { wt. of milled rice }(\mathrm{g})} \\
& \text { Expansion ratio }=\frac{\text { vol. of puffed rice }(\mathrm{mL})}{\text { vol of milled rice }(\mathrm{mL})} \\
& \text { Bulk density }(\mathrm{g} / \mathrm{mL})=\frac{\text { wt of puffed rice }(\mathrm{g})}{\text { vol of milled rice }(\mathrm{mL})}
\end{aligned}
$$

\section{Preparation of salty puffed rice}

Spiced puffed rice was prepared as follow:-In a pan, the puffed rice was toasted at a medium high heat for about 3-4 min. Salt, cumin seeds and red chili powder were finely ground. Then, toasted puffed rice was dusted with the mixed salt and spices. It was cooled down for 3 to $4 \mathrm{hr}$ and then stored it in a clean air tight container.

\section{Preparation of sweet puffed rice balls}

Sweet puffed rice balls were prepared as follow:-In a pan, the puffed rice was toasted at a medium high heat for about 3-4 min. In another pan, sugar cane granule with water were added. Once it melted and boiled, glucose syrup was added and with stirring at a low to medium high heat to prevent it from burning, stirring was done until the syrup well done. The toasted puffed rice was added with strirring on a very low flame until the toasted puffed rice is nicely coated with the syrup mixture. Once it is completely coated, the flame was turned off and cooled down slightly warm enough to handle, for about 3-4 table spoon of the mixture were taken and medium sized balls were formulated and cooled down for 3 to $4 \mathrm{hr}$ and then stored in a clean air tight container.

\section{Sensory properties}

Sensory properties of salty or sweet puffed rice samples were evaluated according to the method of Shen et al, (2014). Salty and sweet puffed rice were evaluated according to their crispness, taste, colour, flavour and overall acceptability, by 10 members of Research Institute of Agricultural, Research Center Al-Giza, Egypt, all samples were coded and presented in a randomized arrangement. Sensory assessment was analyzed using a five-point hedonic scale (1: dislike extremely, 2: dislike, 3: neither, 4: like, 5: like extremely).

\section{Statistical analysis:}

All data were subjected to analysis of variance using Statistical Analysis System (SAS, 1996). Differences among means within the samples were tested using Duncan's multiple range tests at the 5\% probability level.

\section{RESULTS AND DISCUSSION}

\section{Milling and physical characteristics.}

Milling characteristics of different rice varieties namely Sakha101, Giza 178, and Egyptian Jasmine are shown in Table (1). Results show that, Sakha101had the highest significant percentages of brown, milled and head rice and the lowest hulls percentage, followed by Giza 178. For broken rice character, Egyptian Jasmine showed the highest percentage followed by Sakha101 and Giza 178. The results in Table (1) show physical characteristics (length, width, grain shape, grain index and bulk density) of different rice samples.

The data presented in Table (1) indicate that, the length of Basmati rice grains was the highest (7.8mm), followed by Egyptian Jasmine $(6.93 \mathrm{~mm})$ whereas, the length of Sakha 101, Giza 178 rice grains ranged from 4.67 to $5.83 \mathrm{~mm}$, Basmati rice was significantly the longest among all rice samples. Sakha 101 recorded the highest value of width $(2.67 \mathrm{~mm})$ followed by Basmati $(2.03 \mathrm{~mm})$, Egyptian Jasmine $(1.93 \mathrm{~mm})$ and Giza $178(1.83 \mathrm{~mm})$. 
Table 1: Milling and physical characteristics of different rice varieties

\begin{tabular}{|c|c|c|c|c|c|c|c|c|c|c|}
\hline \multirow[b]{2}{*}{$\begin{array}{c}\text { Rice } \\
\text { Samples }\end{array}$} & \multicolumn{5}{|c|}{ Milling characteristics } & \multicolumn{5}{|c|}{ physical characteristics } \\
\hline & $\begin{array}{c}\text { Hulls } \\
(\%)\end{array}$ & $\begin{array}{c}\text { Brown } \\
(\%)\end{array}$ & $\begin{array}{c}\text { Milled } \\
\text { Rice }(\%)\end{array}$ & $\begin{array}{l}\text { Head rice } \\
(\%)\end{array}$ & $\begin{array}{c}\text { Broken } \\
\text { Rice (\%) }\end{array}$ & $\begin{array}{c}\text { Length } \\
(\mathrm{mm})\end{array}$ & $\begin{array}{l}\text { Width } \\
(\mathrm{mm})\end{array}$ & $\begin{array}{l}\text { Grain } \\
\text { shape }\end{array}$ & $\begin{array}{c}\text { Grain } \\
\text { index } \\
(\mathrm{g})\end{array}$ & $\begin{array}{c}\text { Bulk } \\
\text { density } \\
(\mathrm{g} \backslash \mathrm{cm} 3)\end{array}$ \\
\hline Sakha 101 & $18.5 \pm^{\mathrm{o}} .52^{\mathrm{c}}$ & $81.4 \pm 0.79^{a}$ & $71.6 \pm 0.63^{\mathrm{a}}$ & $64.8 \pm 0.78^{\mathrm{a}}$ & $6.8 \pm 0.61^{b}$ & $4.67 \pm 1.10^{c}$ & $2.67 \pm 0.51^{\mathrm{a}}$ & $1.75 \pm 0.298^{\mathrm{b}}$ & $1.94^{b}$ & $0.90^{\mathrm{a}}$ \\
\hline Giza 178 & $22.0 \pm 0.95^{\mathrm{b}}$ & $78.0 \pm 1.18^{\mathrm{b}}$ & $78.0 \pm 1.18^{\mathrm{b}}$ & $63.4 \pm 0.70^{\mathrm{b}}$ & $5.72 \pm 0.60^{\mathrm{b}}$ & $5.83 \pm 0.59^{\mathrm{bc}}$ & $1.83 \pm 0.25^{\mathrm{b}}$ & $3.25 \pm 0.75^{\mathrm{a}}$ & $1.71^{\mathrm{c}}$ & $0.89^{a}$ \\
\hline $\begin{array}{l}\text { Egyptian } \\
\text { Jasmine }\end{array}$ & $24.75 \pm 0.74^{\mathrm{a}}$ & $75.25 \pm 0.61^{\mathrm{c}}$ & $66.08 \pm 0.55^{\mathrm{c}}$ & $56.46 \pm 0.60^{c}$ & $10.73 \pm 0.57^{\mathrm{a}}$ & $6.93 \pm 0.38^{\mathrm{ab}}$ & $1.93 \pm 0.25^{\mathrm{b}}$ & $3.64 \pm 0.63^{\mathrm{a}}$ & $1.99^{\mathrm{b}}$ & $0.85^{\mathrm{c}}$ \\
\hline Basmati & ------ & ------ & ------ & -------- & ------ & $7.8 \pm 0.79^{\mathrm{a}}$ & $2.03 \pm 0.32^{\mathrm{ab}}$ & $3.89 \pm 0.68^{\mathrm{a}}$ & $2.31^{\mathrm{a}}$ & $0.87^{b}$ \\
\hline LSD & 1.5138 & 1.7823 & 1.1856 & 1.3961 & 1.1819 & 1.4370 & 0.6612 & 1.1611 & 0.1713 & 0.0104 \\
\hline
\end{tabular}

Mean of values between varieties having the same superscript within the roware not significantly different at $(p>0.05)$.

"Grain index = weight of 100 grains.

*Each value was an average of ten determinations

+Values followed by the same letter in column are not significantly different at $P \leq 0.01$

As for grain shape the results referred that, Basmati was slender in shape. Whereas, Sakha 101, Giza 178 and Egyption yasmine were bold in shape. Shape as slender $>3.00$, medium (3.01$3.00)$, bold (1.01-2.00) and round $(\leq 1.0)$, according to Ahuja et al., (1995) and Kent \& Evers (1994) classification.

Grain index values of (Sakha 101, Giza 178, Egyptian Yasmine and Basmati) were 1.94, 1.71, 1.99 and $2.31 \mathrm{~g}$, respectively) as shown in Table (1). In addition, the data in the same table revealed that, bulk density was higher in Sakha 101 followed by Giza 178 then Basmati. These results are in agreement with El- Bana et al. (2010).

\section{Proximate chemical composition of milled rice}

Proximate chemical composition of the different milled rice varieties under study is shown in Table (2). There were no significant differences in the protein contents among the rice varieties except for Sakha 101 which possessed the significantly highest protein content $(8.23 \%)$. Also, Basmati rice contained higher contents of ether extract, ash and crude fiber compared with the other varieties. In addition, there were no significant differences in the nitrogen free extract (NFE) content of different milled rice samples. These results are in agreement with Kadan et al., (1997), who found that, the protein content of milled Waxy and Egyptian Jasmine rice were 6.9 and $6.7 \%$ and the lipid content were 0.6 and 0.3 , respectively. Cristina and Cristina (2008) reported that, carbohydrate was the most abundant component in rice, with starch content of approximately $80 \%$ (14\% moisture) while protein was the second abundant constituent of milled rice, ranging from 6.3 to $7.1 \%$. The results in Table (3) show also that, amylose content of Giza 178 variety had significantly the lowest content $(18.65 \%)$ compared to other varieties. The highest content for amylose was found in Basmati variety (32.47\%).

Table 2: Proximate chemical composition and amylose content of different milled rice samples $(\%$ on dry weight)

\begin{tabular}{|c|c|c|c|c|c|c|c|}
\hline $\begin{array}{c}\text { Rice } \\
\text { samples }\end{array}$ & $\begin{array}{c}\text { Moisture } \\
\text { (\%) }\end{array}$ & $\begin{array}{c}\text { Crude } \\
\text { Protein } \\
(\%)\end{array}$ & $\begin{array}{c}\text { Crude } \\
\text { fiber }(\%)\end{array}$ & $\begin{array}{l}\text { ash } \\
(\%)\end{array}$ & $\begin{array}{l}\text { Fat } \\
(\%)\end{array}$ & $(\mathrm{NFE}) *$ & $\underset{(\%)}{\text { Amylose }}$ \\
\hline Sakha101 & $11.43 \pm 0.44^{c}$ & $8.23 \pm 0.44^{a}$ & $0.78 \pm 0.17^{\mathrm{b}}$ & $0.56 \pm 0.16^{b}$ & $0.67 \pm 0.10^{\mathrm{b}}$ & $78.33 \pm 1.22^{\mathrm{a}}$ & $20.09 \pm 0.46^{b}$ \\
\hline Giza178 & $12.73 \pm 0.44 \mathrm{ab}$ & $7.1 \pm 0.44^{b}$ & $0.65 \pm 0.20^{\mathrm{b}}$ & $0.63 \pm 0.17^{\mathrm{ab}}$ & $0.89 \pm 0.29^{\mathrm{ab}}$ & $77.8 \pm 0.36^{a}$ & $18.65 \pm 0.44^{\mathrm{c}}$ \\
\hline $\begin{array}{l}\text { Egyptian } \\
\text { Jasmine }\end{array}$ & $13.3 \pm 0.44^{a}$ & $7.35 \pm 0.36^{\mathrm{b}}$ & $0.91 \pm 0.23^{b}$ & $0.90 \pm 0.29^{\mathrm{a}}$ & $0.66 \pm 0.17 \mathrm{~b}$ & $76.89 \pm 1.33^{\mathrm{a}}$ & $19.1 \pm 0.529$ \\
\hline Basmati & $11.87 \pm 0.53^{\mathrm{bc}}$ & $6.72 \pm 0.44^{b}$ & $1.35 \pm^{\mathrm{o}} .23^{\mathrm{a}}$ & $1.27 \pm 0.29^{\mathrm{a}}$ & $1.24 \pm 0.33^{\mathrm{a}}$ & $1.24 \pm 0.33^{\mathrm{a}}$ & $32.47 \pm 0.70^{\mathrm{a}}$ \\
\hline LSD & 0.8679 & 0.7877 & 0.3402 & 0.4303 & 0.4505 & 1.9363 & 1.0183 \\
\hline
\end{tabular}

$(\mathrm{NFE})^{*}:$ Nitrogen free extract

Means of values between varieties having the same right case letter(s) (small letter within a row) are not significantly different at $(P>0.05)$. 


\section{Cooking quality}

Cooking properties are very important as rice is consumed almost immediately after cooking. Data in Table (3) show that, gel consistency (GC) varied significantly among different varieties. GC in Basmati was the lowest $(82.23 \%)$ compared with the other two rice varieties, Sakha 101 was the highest in $\mathrm{GC}(94.4 \%)$ followed by Giza 178(86.1\%)and Egyptian Jasmine (82.4\% ).

Generally, all varieties are classified under soft rice which their GC ranged between 61-100 mm as described by Cagampanget al.,( 1973). The alkali spreading value for Egyptian Jasmine rice variety showed the lowest value (5.46\%). Meanwhile, Giza178 showed the highest value of alkalis spreading $(6.45 \%)$. Also, Basmati rice required a longer cooking time compared with the other rice varieties. Moreover, it could be noted that the, elongation value of Sakha 101 was higher $(72.05 \mathrm{~mm})$ than those of other varieties $(63.1-6541 \mathrm{~mm})$.

\section{Quality characteristics of different puffed rice samples.}

The quality characteristics of different puffed rice samples are presented in Table (4). Basmati grain showed the highest puffed yield (96.72\%) followed by Egyptian Jasmine rice (96.1\%) and Giza178 (93.56\%). Moreover, Sakha 101 had the highest expansion volume $(2.18 \mathrm{ml} / \mathrm{g})$ compared with other rice varieties, meanwhile, Egyptian Jasmine had the lowest expansion volume $(1.49 \mathrm{ml} / \mathrm{g})$.

There were no significant differences in expansion ratio character for Sakha 101 compared to Giza 178 and Basmati grain. However, Egyptian Jasmine had the lowest expansion ratio. On other hand there were significant differences in bulk density character between Sakha 101 and the other three varieties Giza 178, Egyptian Jasmine and Basmati rice) while there were no significant differences between Basmati rice and Egyptian Jasmine.

Puffing and popping quality of paddy having strongly positive correlation with amylose content which plays an important role in the expansion ratio of rice kernels, higher the amylose content, the higher expansion ratio during puffing (Madhuri, 2002). Maisont \& Narkrugsa (2010) found that, high amylose content resulted in a hard product with low expansion. However, the exact effect of amylose content on puffing quality of rice was not cleared yet, because many other researchers also reported that amylose content had negative correlation with both expansion volume and puffing percentage (Bhat Upadya et al., 2008., Joshi et al., 2014).

Table 3: Cooking quality of different rice varieties

\begin{tabular}{|c|c|c|c|c|c|c|}
\hline Rice samples & $\begin{array}{c}\text { Gel } \\
\text { consistency } \\
(\mathbf{m m})\end{array}$ & $\begin{array}{c}\text { Alkali } \\
\text { spreading } \\
\text { value }\end{array}$ & $\begin{array}{l}\text { Elongation } \\
\quad(\mathbf{m m})\end{array}$ & $\begin{array}{c}\text { Expansion } \\
\text { volume }(\mathrm{ml} / \mathrm{g})\end{array}$ & $\begin{array}{c}\text { Water } \\
\text { absorption } \\
\text { ratio }(\%)\end{array}$ & $\begin{array}{c}\text { Minimum } \\
\text { cooking } \\
\text { time(min) }\end{array}$ \\
\hline Sakha101 & $94.4 \pm 0.80^{\mathrm{a}}$ & $5.96 \pm 0.27 \mathrm{ab}$ & $72.05 \pm 0.79^{a}$ & $220 \pm 17.32^{\mathrm{a}}$ & $200 \pm 17.32^{b}$ & $20 \pm 1.322^{b}$ \\
\hline Giza178 & $86.1 \pm^{\mathrm{o}} .36^{\mathrm{c}}$ & $6.45 \pm 0.36^{\mathrm{a}}$ & $65.41 \pm 0.35$ & $240 \pm 17.32^{\mathrm{a}}$ & $250 \pm 17.32^{\mathrm{a}}$ & $15 \pm 1.32^{\mathrm{c}}$ \\
\hline $\begin{array}{l}\text { Egyptian } \\
\text { Jasmine }\end{array}$ & $82.4 \pm^{\mathrm{o}} .7549^{\mathrm{d}}$ & $5.46 \pm 0.2646^{b}$ & $63.1 \pm 0.4358^{c}$ & $238 \pm 10.58^{a}$ & $180 \pm 17.32^{b}$ & $15 \pm 1.732^{c}$ \\
\hline Basmati & $8223 \pm^{\mathrm{o}} .70^{\mathrm{b}}$ & $5.63 \pm 0.5$ & $63.3 \pm 0.53^{\mathrm{c}}$ & $225 \pm 8.66^{\mathrm{a}}$ & $260 \pm 26.45^{\mathrm{a}}$ & $25 \pm 2.00^{\mathrm{a}}$ \\
\hline LSD & 1.2700 & 0.6788 & 1.0398 & 26.4102 & 37.0656 & 3.0506 \\
\hline
\end{tabular}

Means of values between varieties having the same right case letter(s) (small letter within a row) are not significantly different at $(P>0.05)$.

Table 4: Quality characteristics of different puffed rice samples

\begin{tabular}{|c|c|c|c|c|}
\hline Puffed rice samples & Puffed yield \% & Expansion Volume (ml/g) & Expansion ratio & Bulk density (g/ml) \\
\hline Sakha 101 & $85.20 \pm 0.46^{c}$ & $2.18 \pm 0.26^{\mathrm{a}}$ & $2.20 \pm 0.30^{\mathrm{a}}$ & $0.81 \pm 0.09 \mathrm{c}$ \\
\hline Giza 178 & $93.56 \pm 1.40^{\mathrm{b}}$ & $2.00 \pm 0.30^{\mathrm{ab}}$ & $2.50 \pm 0.29^{\mathrm{a}}$ & $1.20 \pm 0.07^{\mathrm{a}}$ \\
\hline Egyptian Jasmine & $96.10 \pm 0.59^{\mathrm{a}}$ & $1.49 \pm 0.27^{b}$ & $1.50 \pm 0.50^{\mathrm{b}}$ & $0.96 \pm 0.01^{b}$ \\
\hline Basmati & $96.72 \pm 1.04^{\mathrm{a}}$ & $1.99 \pm 0.27 \mathrm{ab}$ & $2.50 \pm 0.36^{\mathrm{a}}$ & $0.97 \pm 0.01^{b}$ \\
\hline L.S.D & 1.7818 & 0.5150 & 0.5803 & 0.1103 \\
\hline
\end{tabular}

Means of values between varieties having the same right case letter(s) (small letter within a row) are not significantly different at $(P>0.05)$. 


\section{Proximate chemical composition of puffed rice}

Proximate chemical composition of different puffed rice samples is shown in Table (5). That, there were significant differences in the protein contents of puffed Sakha $101(7.51 \%)$ and other studied varieties, which were $(6.83,6.81$ and 6.03\%) for puffed Giza 178, puffed Egyptian Jasmine and puffed Basmati rice, respectively.

Puffed Basmati rice contained the highest contents of ash, crude fiber and nitrogen free extract (NFE) compared with that of other different puffed rice samples. In addition, there were no significant differences in protein,fat and (NFE) contents of puffed Giza 178 and puffed Egyptian Jasmine. Also, for total calories, there were significant differences between different puffed rice samples in which puffed Sakha 101 rice exhibited the highest value followed by Giza 178, Egyptian Jasmine and at last Basmati rice.

\section{Organoleptic characteristics of salty puffed rice.}

Organoleptic characteristics of the salty puffed rice (crispness, taste, colour, flavour and overall acceptability) are given in Table (6). The results indicate that, Sakha 101 salty puffed rice gave significantly the highest scores for crispness compared with the other salty puffed rice. In addition, there were no significant differences in flavour, taste and overall acceptability for all salty puffed rice samples.

\section{Organoleptic characteristics of sweet puffed rice balls}

Organoleptic characteristics of the sweet puffed rice balls are recorded in Table (7). Results indicated that all sweet puffed samples showed high acceptability scores for crispness, taste, colour, flavour and overall acceptability. In addition, there were no significant differences in all characteristics except for colour.

Table 5: Proximate chemical composition (\%) on dry weight and Total calories of different puffed rice samples

\begin{tabular}{lcccccccc}
\hline $\begin{array}{c}\text { Rice } \\
\text { samples }\end{array}$ & $\begin{array}{c}\text { Moisture } \\
(\%)\end{array}$ & $\begin{array}{c}\text { Crude } \\
\text { Protein } \\
(\%)\end{array}$ & $\begin{array}{c}\text { Crude } \\
\text { fiber (\%) }\end{array}$ & $\begin{array}{c}\text { Ash } \\
(\%)\end{array}$ & $\begin{array}{c}\text { Fat } \\
(\%)\end{array}$ & $\begin{array}{c}\text { (NFE)* } \\
\text { Amylose } \\
(\%)\end{array}$ & $\begin{array}{c}\text { Total } \\
\text { Calories }\end{array}$ \\
\hline Sakha101 & $5.88 \pm 0.27^{\mathrm{a}}$ & $7.51 \pm 0.15^{\mathrm{a}}$ & $0.71 \pm 0.06^{\mathrm{bc}}$ & $0.59 \pm 0.12^{\mathrm{b}}$ & $31.21 \pm 1.55^{\mathrm{a}}$ & $54.10 \pm 1.61^{\mathrm{c}}$ & $18.10 \pm 0.22^{\mathrm{b}}$ & $527.33 \pm 8.20^{\mathrm{a}}$ \\
Giza178 & $6.15 \pm 0.18^{\mathrm{a}}$ & $6.83 \pm 0.08^{\mathrm{b}}$ & $0.62 \pm 0.06^{\mathrm{c}}$ & $0.62 \pm 0.07^{\mathrm{b}}$ & $28.29 \pm 1.21^{\mathrm{b}}$ & $57.82 \pm 1.52^{\mathrm{b}}$ & $16.79 \pm 0.14^{\mathrm{c}}$ & $511.89 \pm 7.05^{\mathrm{b}}$ \\
$\begin{array}{l}\text { Egyptian } \\
\text { Jasmine }\end{array}$ & $6.21 \pm 0.25^{\mathrm{a}}$ & $6.81 \pm 0.18^{\mathrm{b}}$ & $0.85 \pm 0.07^{\mathrm{b}}$ & $0.97 \pm 0.16^{\mathrm{a}}$ & $27.66 \pm 0.19^{\mathrm{b}}$ & $57.49 \pm 0.22^{\mathrm{b}}$ & $16.56 \pm 0.19^{\mathrm{c}}$ & $506.15 \pm 0.28^{\mathrm{b}}$ \\
Basmati & $6.18 \pm 0.33^{\mathrm{a}}$ & $6.03 \pm 0.27^{\mathrm{c}}$ & $1.23 \pm 0.12^{\mathrm{a}}$ & $1.11 \pm 0.13^{\mathrm{a}}$ & $18.29 \pm 0.15^{\mathrm{c}}$ & $67.16 \pm 0.17^{\mathrm{a}}$ & $25.97 \pm 0.19^{\mathrm{a}}$ & $456.37 \pm 0.49^{\mathrm{c}}$ \\
LSD & 0.4961 & 0.3418 & 0.1521 & 0.2346 & 1.8664 & 2.0985 & 0.3538 & 10.1939 \\
\hline
\end{tabular}

(NFE)* : Nitrogen free extract

Means of values between varieties having the same superscript within therow are not significantly different at $(\mathrm{P}>$ $0.05)$.

Table 6: Sensory evaluation of salty puffed rice samples

\begin{tabular}{llllll}
\hline $\begin{array}{c}\text { Salty puffed rice } \\
\text { Samples }\end{array}$ & \multicolumn{1}{c}{$\begin{array}{c}\text { Crispness } \\
\mathbf{( 5 )}\end{array}$} & \multicolumn{1}{c}{$\begin{array}{c}\text { Taste } \\
\mathbf{( 5 )}\end{array}$} & $\begin{array}{c}\text { Colour } \\
\mathbf{( 5 )}\end{array}$ & $\begin{array}{c}\text { Flavour } \\
\mathbf{( 5 )}\end{array}$ & $\begin{array}{c}\text { Overall } \\
\text { acceptability(5) }\end{array}$ \\
\hline Sakha 101 & $4.30 \pm 0.54^{\mathrm{a}}$ & $4.50 \pm 0.53^{\mathrm{a}}$ & $4.00 \pm 0.62^{\mathrm{b}}$ & $4.40 \pm 0.52^{\mathrm{a}}$ & $4.30 \pm 0.44^{\mathrm{a}}$ \\
Giza 178 & $4.10 \pm 0.61 \mathrm{a}^{\mathrm{b}}$ & $4.06 \pm 0.60^{\mathrm{a}}$ & $3.95 \pm 0.76^{\mathrm{b}}$ & $4.50 \pm 0.53^{\mathrm{a}}$ & $4.15 \pm 0.40^{\mathrm{a}}$ \\
Egyptian Jasmine & $4.05 \pm 0.37 \mathrm{a}^{\mathrm{b}}$ & $4.23 \pm 0.34^{\mathrm{a}}$ & $4.20 \pm 0.75^{\mathrm{ab}}$ & $4.55 \pm 0.50^{\mathrm{a}}$ & $4.26 \pm 0.38^{\mathrm{a}}$ \\
Basmati rice & $3.85 \pm 0.34^{\mathrm{b}}$ & $4.40 \pm 0.57^{\mathrm{a}}$ & $4.72 \pm 0.45^{\mathrm{a}}$ & $4.55 \pm 0.50^{\mathrm{a}}$ & $4.38 \pm 0.35^{\mathrm{a}}$ \\
LSD & 0.4342 & 0.4704 & 0.5986 & 0.4622 & 0.613925 \\
\hline
\end{tabular}

Data are presented as means \pm SDM $(n=10$, a 5-point hedonic scale) Means of values between varieties having the samesuperscript within the row are not significantly different at $(\mathrm{P}>0.05)$. 
Table (7) Sensory evaluation of sweet puffed rice balls.

\begin{tabular}{llcccc}
\hline \multicolumn{1}{c}{$\begin{array}{c}\text { Sweet puffed } \\
\text { rice balls }\end{array}$} & \multicolumn{1}{c}{$\begin{array}{c}\text { Crispness } \\
\mathbf{( 5 )}\end{array}$} & \multicolumn{1}{c}{$\begin{array}{c}\text { Taste } \\
\mathbf{( 5 )}\end{array}$} & $\begin{array}{c}\text { Colour } \\
\mathbf{( 5 )}\end{array}$ & $\begin{array}{c}\text { Flavour } \\
\mathbf{( 5 )}\end{array}$ & $\begin{array}{c}\text { Overall } \\
\text { acceptability( 5) }\end{array}$ \\
\hline Sakha 101 & $4.35 \pm 0.58^{\mathrm{a}}$ & $4.5 \pm 0.47^{\mathrm{a}}$ & $4.5 \pm 0.47^{\mathrm{a}}$ & $4.6 \pm 0.52^{\mathrm{a}}$ & $4.51 \pm 0.40$ \\
Giza 178 & $4.60 \pm 0.52^{\mathrm{a}}$ & $4.6 \pm 0.57^{\mathrm{a}}$ & $4.1 \pm 0.74^{\mathrm{ab}}$ & $4.55 \pm 0.50^{\mathrm{a}}$ & $4.46 \pm 0.47^{\mathrm{a}}$ \\
Egyptian Jasmine & $4.55 \pm 0.60^{\mathrm{a}}$ & $4.8 \pm 0.42^{\mathrm{a}}$ & $4.5 \pm 0.47^{\mathrm{ab}}$ & $4.7 \pm 0.48^{\mathrm{a}}$ & $4.65 \pm 0.31^{\mathrm{a}}$ \\
Basmati rice & $4.60 \pm 0.46^{\mathrm{a}}$ & $4.7 \pm 0.42^{\mathrm{a}}$ & $4.9 \pm 0.32^{\mathrm{a}}$ & $4.85 \pm 0.34^{\mathrm{a}}$ & $4.76 \pm 0.27^{\mathrm{a}}$ \\
LSD & 0.4909 & 0.4302 & 0.473 & 0.421 & 0.336 \\
\hline
\end{tabular}

Data are presented as means \pm SDM $(n=10$, a 5 -point hedonic scale)

Means of values between varieties having the same superscript within the roware not significantly different at $(P>$ $0.05)$.

\section{REFERENCES}

A.O.A.C. 1995. Official methods of analysis, 15th edn. Association of Official Analytical Chemists, Washington

A.O.A.C. 2010. Association of Official Analytical Chemists.Official Methods of Analysis, $19^{\text {th }}$ ed. Washington, D.C.

Ahuja, S.C., Panwar D.V., Ahuja U. \& Gupta K.R. 1995. Basmati rice: The scented pearl, pp. 1-61. Hiusar, Haryana, India: Directorate of Pub., CCS Har-yhana Agricultural University.

Bhat Upadya V.G., Bhat R.S., Shenoy V.V. \& Salimath P.M. 2008. Physico-chemical characterization of popping-Special Rice Accessions.Karnataka Journal of Agricultural Sciences, 21: 184-186.

Bhattacharya, K.R. \& Sowbhagya 1980. Size and shape classification of rice. Riso, 29: 181185.

Cagampang, G.B., Perez, C.M. \& Juliano, B.O. 1973. A gel consistency test for eating quality of rice, Journal of Science and Food Agriculture, 24: 1589 - 1594.

Chandrasekhar PR \& Chattopadhyay PK. 1991. Rice puffing in relation to its varietal characteristics and processing conditions. Journal of Food ProcessEngineering, 14: 261-277.

Chinnaswamy R and Bhattacharya K R. 1983.Studies on expanded rice. Optimum condition processing conditions. Journal of Food Science., 48:1605-1608.

Cristina M. R. \& CristinaM. 2008. Gluten-free cereal products and beverages. (Rice) ISBN: 9780123737397. Elsevier Inc., pp.81-100.
Department of Agriculture, Cooperation \&Farmers Welfare, 2017. Annual report, 2016-17. Department of Agriculture, Cooperation \& Farmer's Welfare.Ministry of agriculture \& farmer's welfare, Government of India.

El- Bana , M. A. , Wafaa ,K. Galal \& Soher T. ElHadidie. 2010. Physico-chemical and technological studies on some Egyptian rice varieties. Journal of Food and Dairy Sciences, 1: 161-172.

Food and Drink Administration (FDA) 2006. Guidance for Industry and FDA Staff. Whole grainlabel statements draft guidance.

Available at: http://www.cfsan.fda.gov/ dms /flgragui.html last accessed December 2008.

Hoke K., Houšová J., Houška M. 2005: Optimum conditions of rice puffing Review. Czech Journal of Food Sciences, 23: 1-11.

Joshi ND, Mohapatra D and Joshi DC. 2014. Varietal selection of some indica rice for production of puffed rice. Food and Bioprocess Technology, 7: 299-305.

Juliano, B.O., Perez, C.M., Blakeney, A.B., Castillo, D.T., Kongseree, N., Laignelet, B., Lapis, E.T., Murty, V.V.S., Paule, C.M \& Webb, B.D. 1981. International cooperative testing on the amylose content of milled rice. Starch/ Staerke, 33: 157-162.

Kadan, R.S., Champagne, E. T., Ziegler, G. M. \& Richard, O. A. 1997. Amylose and protein contents of rice cultivars as related to texture of rice- based fries. Journal of Food Science., 62: 701-703.

Kent, N.L. and A.D. Evers, 1994. Technology of cereals, 4th Ed., El-Sevier Science Inc., 660 White Plains Road, Torrytown, New York, 105, 951-553 USA. 
Khan, A.U. \& Wikramanayake, V.E.A. 1971. A laboratory test tube miller, IRR. Agric. Eng. Dept. pp: 71-80.

Maisont, S. \& Narkrugsa W. 2009. Effects of some physicochemical properties of paddy rice varieties on puffing qualities by microwave. Kasetsart Journal Natural Science. 43: 566 - 575.

Maisont, S. \& Narkrugsa W 2010. Effects of salt, moisture content and microwave power on puffing qualities of puffed rice. Kasetsart Journal Natural Science. 44: 251-261.

Madhuri, S. K. 2002. Varietal Suitability of Rice (Oryza sativa L.) for Conventional Processing. M.Sc. Thesis, University of Agricultural Sciences, Dharwad.

Murugesan G. \& Bhattacharya, K.R. 1991. Basis for varietal difference in popping expansion of rice. Article in Journal of Cereal Science, 13:71-83.

Myklestad, O., Christie, E.M., Coate, G.G. \& Mcdonadl, D.J. 1968. Chemical, physical and organoleptic properties of 12 varieties of rice, Division of Food Preservation, Technical Paper, 33: 19 Commonwealth Sci. and Industrial Res. Organization, Australia.

S.A.S. 1996. Statistical Analysis System for windows. In. S.A.S. stat user's guide, version 4.10, release 6.12 SAS Institute Inc. Cary. Ne. USA.
Seal, C. J., A.R. Jones \& A. D. Whitney. 2006. Whole grains uncovered. Nutrition Bulletin, 31: 129-137.

Shen, X.J., J.Y. Han, \& G.H. Ryn. 2014. Effects of the addition of green tea powder on the quality and antioxidant properties of vacuumpuffed and deep-fried Yukwa (rice snacks). Food Research International. 37: 362-367.

Shih, F., King, J., Daigle, K., An, H. J., \& Ali, R. 2007. Physicochemical properties of rice starch modified by hydrothermal treatments. Cereal Chemistry, 84, 527-531.

Simsrisakul, M. 1991. Important Factors Affecting Puffing Quality of Paddy and Properties of Puffed Rice Flour. M.Sc. Thesis. Chulalongkorn University. Bangkok.

Sullivan, J.F. \& Craig, J.D. 1984. The development of explosion puffing. Food Technology, 38: 52-55, 131.

Suwansri, S. \& Meullenent, J. 2004. Physicochemical characterization and consumer acceptance by Asian consumers of aromatic jasmine rice. Journal of Food Science, 69: 30-37.

Tomar, J.B. 1985. Studies on the inheritance of kernel size and its association with physical and chemical quality characters in rice, $\mathrm{Z}$. Pflanzenzucht, 95: 361-366. 


\section{الخصائص الطبيعيةو الكيماوية وخصائص الطهو لبعض أصناف الأرز

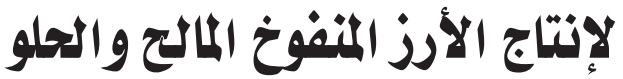

وفاء كمال جلال ، رفاعى جمعه على، مها منير توفيق

قسم بحوث تكنولوجيا المحاصيل - معهد بحوث تكنولوجيا الأغذية - مركز البحوث الزراعية

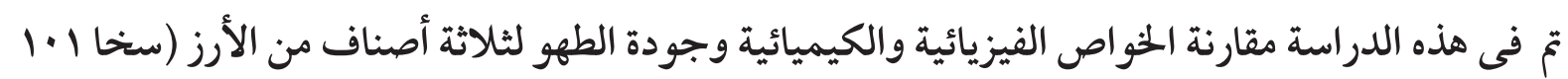

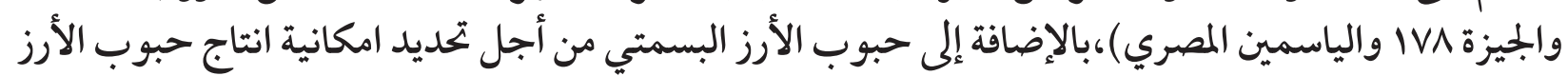

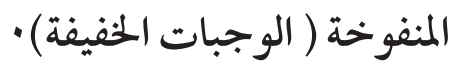

أظهرت النتائج أن صنف سخا 1 ـ أعطى أعلى نسبة من الأرز البني والأرز الابيض والحبوب السليمة

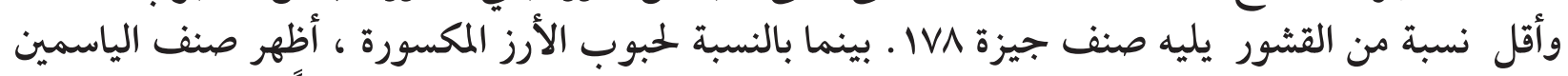

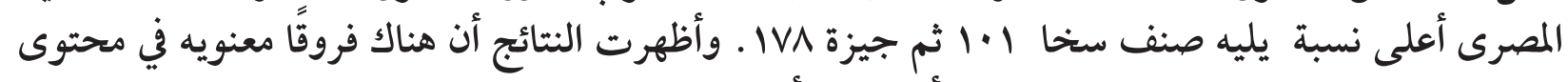

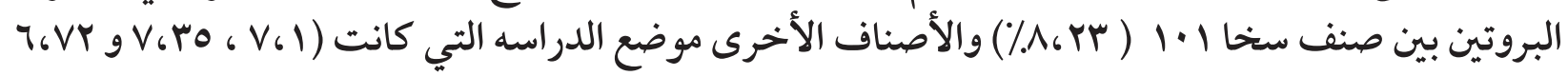

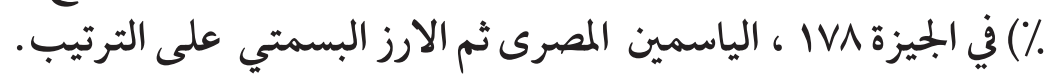

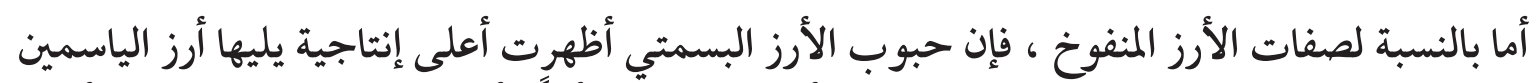

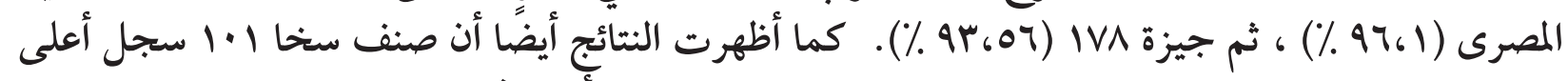

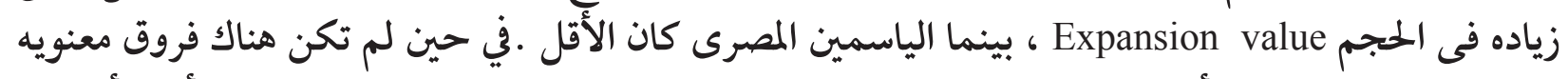

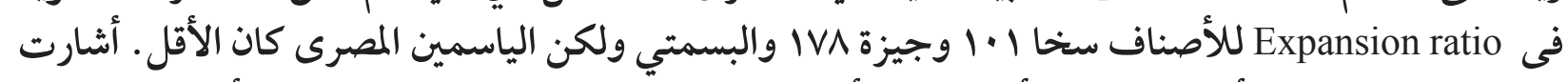

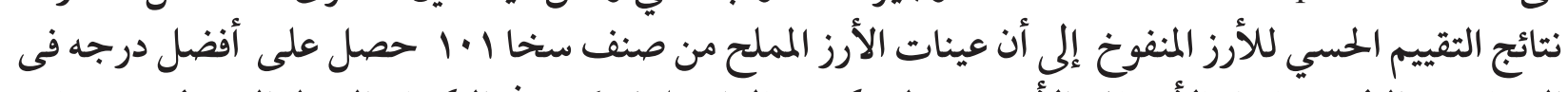

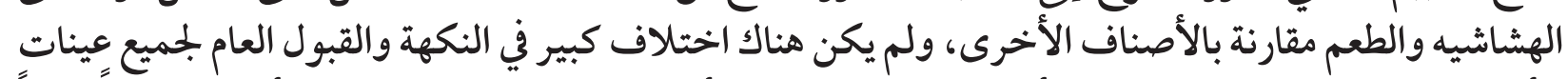

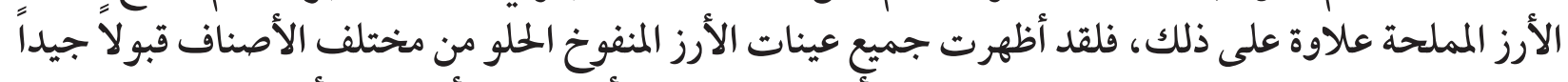

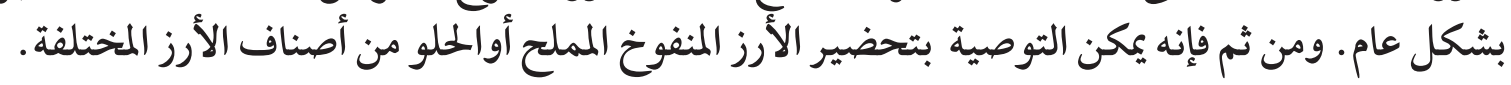


